\title{
A Review of Corrosion Control Methods in Ferrocement
}

\author{
Akhtar S ${ }^{1}$, Md. Daniyal ${ }^{1}$ and Quraishi MA ${ }^{2 *}$ \\ ${ }^{1}$ Department of Civil Engineering, Aligarh Muslim University, Aligarh, India \\ ${ }^{2}$ Department of Chemistry, Indian Institute of Technology BHU, Varanasi, India
}

\begin{abstract}
Ferrocement is a composite material consisting of layered wire meshes and rich cement-sand mortar which imparts high degree of ductility and energy absorbing capacity. Although ferrocement has proven itself as an excellent material for low cost housing, its durability continues to be a matter of concern owing to the corrosion susceptibility of the small diameter metallic wire meshes. Protection of reinforcement in ferrocement is usually achieved through the galvanized wire mesh, increased effective cover and dense mortar. These methods give only partial protection to the reinforcement against corrosion. This article reviews the studies undertaken to control corrosion in the ferrocement composites and thereby improving the durability of the composites.
\end{abstract}

Keywords: Ferrocement; Cementitious composites; Corrosion of steel wire mesh; Corrosion inhibitors

\section{Introduction}

There is an alarming housing shortage in Asia and the Pacific region in general and in the Indian context in particular. An economical and a simple alternative construction material will contribute greatly in solving the problem of housing. The provision of proper dwellings and basic infrastructure facilities along with earthquake resistant features, have been the constant endeavour of the previous researchers. Ferrocement has proven itself as an excellent material for low cost earthquake resistant housing. Various research organisations and non-government agencies viz. CBRI, SERC, AVBC, HUDCO and some other private sector organisations have also been involved in propagating the technology for effective use of ferrocement units. The corrosion susceptibility puts a question mark on the effective service life of ferrocement and its components. Any technique suggesting the enhanced life through use of corrosion inhibitors will definitely establish the effectiveness of the ferrocement material system for a wider range of application in diversified areas including housing, agriculture, industrial, terrestrial and marine etc. Success of ferrocement, as with other material depends largely upon its durability. Although the ferrocement has proven itself as an excellent material for low cost housing [1-20], reinforcement corrosion is one of the most important criterion governing durability of the ferrocement since the diameter of the wire meshes used in ferrocement are much smaller as compared to the conventional reinforced cement concrete.

\section{Prevalent Corrosion Control Techniques}

Protection of reinforcement is usually achieved through the use of galvanized wire mesh [21]. It has also been suggested that the corrosion of reinforcement can be checked to some extent by making dense mortar with the use of additives such as fly ash, silica fumes and blast furnace slag [22-24]. Some researchers have reported the improvement by increasing the effective cover [25]. These suggested ways have proved to be ineffective with the passage of time thereby reducing the strength of the ferrocement components [26,27]. Studies undertaken on the chemical reactivity of inhibitors by earlier investigators highlight the worthiness of its application [28-30]. ACI-549R strongly recommends that studies be undertaken to suggest durable and long term anti-corrosion techniques to prevent penetration of water and salts that could lead to the corrosion of reinforcing wire mesh [31]. In some of the recent studies carried out to protect rebar in concrete using different types of corrosion inhibitors, it has been clearly established that inhibitors are extremely effective in controlling/delaying onset of corrosion [32-39].

\section{Use of Chemical Corrosion Inhibtors}

Use of chemical corrosion inhibitor in ferrocement is rarely sighted in literature. Only a few studies are reported which deal with the chemicals like chromium trioxide to address a particular problem of galvanic cell, a patented admixture and a polymer-modified coating to control the reinforcement corrosion.

Use of chemical admixture for the control of corrosion in ferrocement has been explored by a very few investigators. The use of galvanized wire mesh along with the un-galvanized skeletal steel bars creates galvanic cell problem. Christensen and Williamson [40] were first to identify this problem and also gave the solution. They suggested the use of chromium trioxide at the rate of $100-300 \mathrm{ppm}$ by weight of water in preparing the mortar. Iorns [41] also reported the use of chromium trioxide as an inhibitor of hydrogen gas generation when galvanized mesh is used in ferrocement. Rengaswamy, Saraswathy and Balakrishnan [42] recommended the use of a patented admixture inhibitor consisting of one or more of the chemicals, namely trisodium phosphate, sodium nitrite, sodium hydroxide and sodium carbonate, for the protection of reinforcement against corrosion due to chloride concentration in ferrocement. Shirai and Ohama [43] reported the performance of ferrocement with polymer-modified coating on reinforcement. The coating paste was prepared using styrene-butadiene rubber latex. It was concluded that the corrosion inhibiting property is remarkably improved.

In some of the recent studies attempts has been made to improve the corrosion resistance of the ferrocement. Akhtar, et al. [44] explored the

*Corresponding author: Quraishi MA, Department of Chemistry, Indian Institute of Technology BHU, Varanasi, India, Tel: 0542236 8558; E-mail: maquraishi.apc@itbhu.ac.in

Received October 24, 2015; Accepted November 19, 2015; Published November 26, 2015

Citation: Akhtar S, Daniyal, Quraishi MA (2015) A Review of Corrosion Control Methods in Ferrocement. J Steel Struct Constr 1: 103. doi:10.4172/24720437.1000103

Copyright: (C) 2015 Akhtar S, et al. This is an open-access article distributed under the terms of the Creative Commons Attribution License, which permits unrestricted use, distribution, and reproduction in any medium, provided the original author and source are credited. 
use of calcium nitrite and tannic acid as potential corrosion inhibitor for ferrocement. It was observed that one of the foremost reasons affecting the durability of ferrocement is the corrosion of wire meshes. This problem magnifies manifolds under aggressive environment. With the passage of time the effective strength of the wires reduces due to reduction in diameter and also due to the deterioration of the bond between the matrix and reinforcement. In the study, an attempt has been made to improve the corrosion resistance of the metallic wire meshes used in ferrocement by corrosion inhibitors. Two corrosion inhibitors viz. Calcium Nitrite and Tannic Acid were used. Weight loss studies and potentio-dynamic polarization tests were conducted in saline water medium. Corrosion efficiency and Corrosion rate were calculated. It was concluded that the both the corrosion inhibitor exhibited appreciable level of corrosion inhibition.

Akhtar, et al. [45] carried out tests on steel wire mesh that is used as reinforcement in ferrocement. They attempted to improve the corrosion resistance of steel wire mesh in bare medium using corrosion inhibitors. The concentration of corrosion inhibitors and the salinity were varied. Gravimetric weight loss and Potentio-dynamic polarization tests were conducted. The level of efficiency exhibited by Type-I inhibitor for all the type of specimen is excellent. Under all the exposure conditions, Type-I inhibitor delays the onset of corrosion which leads to the reduction of corrosion rate. Type-II inhibitor also exhibits reasonably good efficiency there by a lower corrosion rate. The results of weight loss study and potentio-dynamic study are confirmatory to each other. Shaktivel and Jagannathan [46] conducted test on ferrocement slab specimen using PVC coated mesh reinforcenet. Excellent results were observed on account of corrosion eradication in ferrocement. When the specimen were tested in flexure the problem of early debonding were observed.

\section{Conclusion}

User friendly, easily available, non-patented and cost effective chemical corrosion inhibitor for ferrocement is need of the day. The dose of corrosion inhibitor and its effective application technique also need to be explored. The adverse effect on setting time of cement, compressive and tensile strength of cement-sand mortar has rarely been discussed in the available literature. Hence, there is a wide scope left to suggest new dimensions and new methodology, which can seize/ reduce the corrosion, with the passage of time, thereby adding extra life to the structure.

\section{References}

1. Rao PS, Achyuta H, Mathews MS, Srinivasan PP (1981) Impact Studies on Ferrocement Slabs. Proceedings of RILEM/ISMES on Ferrocemnet, Bergamo, Italy.

2. Bennett EW, Fakhri NA, Singh G (1985) Fatigue Characteristics of Ferrocement in Flexure. ACl Journal 82: 129-135.

3. Achyuta H, Mathews MS, Rao PS (1988) Assessment of Impact Resistance of Ferrocement Slabs. Proceedings Third International Symposium on Ferrocement, India.

4. Desayi P (1988) Ferrocement-Some Ideas on Future Thrust Areas in Research, Applications and Technology Transfer. Proceedings Third International Symposium on Ferrocement, University of Roorkee, India.

5. Desai JA, Desai MD (1988) Ferrocement Roofing Element for Low Cost Housing. Proceedings Third International Symposium on Ferrocement.

6. Trikha DN, Sharma PC, Johnson S (1988) Rehabilitation of Corrosion Damaged Steel Tanks by Ferrocement Treatment at University of Roorkee. Proceedings Third International Symposium on Ferrocement, Roorkee, India.

7. Kobayashi Y, Tanaka Y, Ono M (1992) Flexural Impact Damage of Ferrocement. Journal of Ferrocement 22: 249-263.
8. Hermosura NK, Austriaco LR (1994) Research on Ferrocement HousingGlobal Perspective. Journal of Ferrocement 24: 1-6.

9. Mathews MS, Prakash VS, Shaji TL (1994) Ribbed Ferrocement Elements for Low Cost Housing. Journal of Ferrocement 24: 35-49.

10. Ramli M, Wahab I (1994) Ferrocement in Affordable Housing Construction: The Malaysian Experience. Journal of Ferrocement 24: 17-21.

11. Rivas HW (1994) Low Cost Housing Built with Ferrocement Precast Elements. Journal of Ferrocement 24: 29-34.

12. Suresh V, Singh DP (1994) Earthquake Resistant Design and Construction of Houses- HUDCO Experiences. Proceedings $10^{\text {th }}$ ISET, University of Roorkee, India.

13. Pande AM, Patil AB, Waghe UP (1997) Performance of Pre Cast Ferrocement Elements in Low Cost Housing, International Conference on Habitat and Sustainable Development, Institution of Engineers, India.

14. Arif M, Pankaj, Kaushik SK (1998) Experimental Studies on Fatigue and Impact Characteristics of Ferrocement Plates. Journal of Ferrocement 28: 247-256.

15. Arif M, Kaushik SK, Pankaj (1998) Experimental and Analytical Studies on Flexural Behaviour of Ferrocement Plates. Proceedings of $6^{\text {th }}$ International Symposium on Ferrocement, University of Michigan, Michigan, USA.

16. Olvera LA, Olvera F, Martinez R, Almeida F, Olvera AE, et al. (1998) Applications of Prefabricated Ferrocement Housing in Mexico. Proceedings of $6^{\text {th }}$ International Symposium on Ferrocement, University of Michigan, Michigan, USA.

17. Osorio SM, Rivas HW (1998) Technology for Prefabrication and Assembling of Light Ferrocement Panels. Proceedings of $6^{\text {th }}$ International Symposium on Ferrocement, USA.

18. Arif M, Pankaj, Kaushik SK (1999) Mechanical Behaviour of Ferrocement Composites: An Experimental Investigation. Cement and Concrete Composites 21: 301-312.

19. Arif M, Akhtar S, Masood A, Garg M, Basit F (2001) Flexural Behaviour of Fly Ash Mortar Ferrocement Panels for Low Cost Housing. Journal of Ferrocement 31: 125-135.

20. Pankaj, Arif M, Kaushik SK (2002) Mechanical Behaviour of Ferrocement Composites: Numerical Simulation. ASCE Journal of Materials in Civil Engineering 14: 156-163.

21. Masood A, Arif M, Akhtar S, Haquie M (2003) Performance of Ferrocement Panels in Different Environments. Cement and Concrete Research 33: 555-562.

22. Vicridge IG, Ranjabar MM (1998) The Effect of Aggressive Environment on the Flexural Performance of Ferreocement. Proceedingsof $6^{\text {th }}$ interational symposium on Ferrocement, University of Michigan, Ann Arbor, USA.

23. Vickridge IG, Ranjabar MM (1998) The Combined Effect of Crack Load and Aggressive Environment on the Flexural Performance of Ferreocement. Proceedingsof $6^{\text {th }}$ interational symposium on Ferrocement. University of Michigan, Ann Arbor, USA.

24. Dotto (2004) Influence of Silica Fume Addition on Concrete Physical Properties and on Corrosion Behaviour of Reinforcing Bars. Cement and Concrete Composites 26: 31-39.

25. Vickridge IG, Nakassa AS, Turner H (1998) High Durability Ferrocement Proceedings of $6^{\text {th }}$ interational symposium on Ferrocement. University of Michigan, USA.

26. Torri K, Kawamura M (1990) Chloride Induced Corrosion of Steel Reinforcement Made With Various Mineral Admixtures. Trans. Jpn Conc Inst 12:183-190.

27. Ramesht MH (1995) Effect of corrosion on Flexural Behaviour of Ferrocement in Corrosive Environment. Journal of Ferrocement 27: 7-18.

28. Kilareski WP (1980) Corrosion Induced Deterioration of Rienforced Concrete An Overview. Material Performance 19: 48-50.

29. Whiting D (1979) Influence of Concrete Materials, Mix, and Construction Practices on Corrosion of Reinforcing Steel. Material Performance 17: 9-15.

30. Rosenberg AM, Gaidis JM (1978) The mechanism of Nitrite Inhibitor of Chloride attack on Reinforcing steel in Alkaline aqueous Environment. Materia Performance 17: 45-48.

31. ACl 549R-97 (1997) State of Art Report on Ferrocement. ACI Committee 549, American Concrete Institute. 
32. Giadis JM (2004) Chemistry of Corrosion Inhibitors. Cement and Concrete Composites 26: 181-189.

33. Berke NS, Hicks MC (2004) Predicting Long Term Durability of Steel Reinforced Concrete with Calcium Nitrite Corrosion Inhibitor. Cement and Concrete Composites 26: 191-198.

34. Nmai CK (2004) Multi-Functional Organic Corrosion Inhibitor. Cement and Concrete Composites 26: 199-207.

35. Wombacher F, Maeder U, Marrazzani B (2004) Amino-Alcohol Based Mixed Corrosion Inhibitors. Cement and Concrete Composites 26: 209-216.

36. Quian S, Cusson D (2004) Electrochemical Evaluation of the Performance of Corrosion Inhibiting System in Concrete Bridges. Cement and Concrete Composites 26: 217-233.

37. Malik AU (2004) Studies on Performance of Migratory Corrosion Inhibitors in Protection of Rebar Concrete in Gulf Sea Water Environment. Cement and Concrete Composites 26: 235-242.

38. Montes P, Bremner TW, Liester DH (2004) Influence of Calcium Nitrite Inhibitor and Crack Width on Corrosion of Steel in High Performance Concrete Subjected to Simulated Marine Environment. Cement and Concrete Composites 26: 243-253.

39. Vayasburd AM, Emmons PH (2004) Corrosion Inhibitors and other Protective Systems in Concrete Repair: Concepts and Misconcepts. Cement and Concrete Composites 26: 255-263.
40. Christensen KA, Williamson RB (1971) Solving the Galvanic Cell Problem in Ferrocement. Report No. UC SESM71-14, University of California, Berkeley, USA

41. Iorns ME (1984) Corrosion and Corrosion Prevention in Ferrocement Hulls. Journal of Ferrocement.

42. Rengaswamy NS, Balasubramanian TM, Sarsaswati N, Saraswathi R (1987) Monitoring of Reinforcement Corrosion by Potential Measurement. Proceedings of the International Correspondence Symposium, Bangkok, Thailand.

43. Shirai A, Ohama Y (1988) Improvement in Flexural Behaviour and Impact Resistance of Ferrocement by Use of Polymers. Proceedings Third International Conference on Ferrocement, Roorkee, India.

44. Akhtar S, Quraishi MA, Arif M (2009) Use of Chemical Corrosion Inhibitors for Protection of Metallic Fibre Reinforcement in Ferrocement Composites. Arabian Journal for Science and Engineering. 34(2C), USA.

45. Akhtar S, Arif M, Quraishi MA (2007) Inhibition Performance of Some Corrosion Inhibitors for Ferrocement. $2^{\text {nd }}$ National Conference on Recent Trends in Concrete composites for Structural Systems (RTCCSS-07), Organised by SERC, Chennai and KONGU Engineering College, Erode, Tamilnadu, India.

46. Sakthivel PB, Jagannathan A (2012) Corrosion-free cementitious composites for Sustainability. Proceedings of $37^{\text {th }}$ Conference on Our World in Concrete \& Structures, Singapore. 